\title{
University Students'vs. Lay People's Perspectives on Organ Donation and Improving Health Communication in Poland
}

\author{
Wojciech Boratyński \\ ORCID: https://orcid.org/0000-0002-9403-2876 \\ (Warsaw Medical University, bwojtek@ymail.com) \\ Grażyna Bączek \\ ORCID: https://orcid.org/0000-0001-7897-9499 \\ (Warsaw Medical University, gbaczek@wum.edu.pl)
}

Agnieszka Dyzmann-Sroka

ORCID: https://orcid.org/0000-0003-0555-1787

(Medical University, Poznań, agnieszka.dyzmann-sroka@wco.pl)

\section{Agnieszka Jędrzejczak}

ORCID: https://orcid.org/0000-0002-9680-5406

(Greater Poland Cancer Center in Poznań, agnieszka.jedrzejczak@wco.pl)

\author{
Aleksandra Kielan \\ ORCID: https://orcid.org/0000-0001-6265-4593 \\ (Warsaw Medical University, aleksandra@kielan.eu) \\ Paulina Mularczyk-Tomczewska \\ (Warsaw Medical University, mularczyk.paulina@gmail.com) \\ Ewa Nowak \\ ORCID: https://orcid.org/0000-0002-5722-7711 \\ (Adam Mickiewicz University in Poznań, ewanowak@amu.edu.pl) \\ Małgorzata Steć \\ ORCID: https://orcid.org/0000-0002-1841-9542 \\ (Jesuit University Ignatianum, Cracow, malgorzata.stec@gmx.com) \\ Mariusz Szynkiewicz \\ ORCID: https://orcid.org/0000-0001-8595-840X \\ (Adam Mickiewicz University in Poznań, marszyn@amu.edu.pl)
}

\section{General Societal Assessment of Organ Donation in Poland}

"Every year, over 1,000 various organ transplants are carried out in Poland" (Antos \& Zelman 2016, 2; see also Theodorakopoulou et al. 2017, 1-10). With regard to the willingness to donate organs ex mortuo, research conducted by CBOS $(2012,2)$ in 2003-2011 revealed just a slight hesitation (between 74\% - 85\%) in a group of randomly selected respondents. Then, in the years 2011 and 2012, the number of people who were "definitely" ready to be organ donors after their death dropped significantly, by as much as $19 \%$. At the same time, the number of people who were "somewhat" inclined to become donors increased by $8 \%$, while the number of skeptics increased by $7 \%$. In 2012-2016 people's willingness increased to 80\%. In the opinion of the CBOS experts, general skepticism regarding transplantation should be explained by the awareness that 
the organs, tissue and cells acquired through donation can be used for a wide variety of purposes, which are part therapeutic and part non-therapeutic, such as diagnostics, scientific experiments (Nestorowicz \& Śliwka 2009), education, etc.

There could be many reasons for such a regression. Research has shown that willingness to donate correlates with the age of the repondents, thus mature and elderly people are considerably less willing to donate than young people. It can be surmised that an increased attachment to the integrity of one's own body could explain the rise of religiosity among elderly people and, consequently, the rise in the belief in immortality, understood in psychosomatic terms ${ }^{1}$. For more or less explicit religious reasons ${ }^{2}$, in Polish society the principle of the integrity and sacrosanctity of human body seem to prevail. According to McCormick, "this respects a widespread moral conviction that the bodily integrity of the donor must play a decisive restraining role in the ethical assessment of organ transplants" (McCormick 1978, 1172). Moreover, Pope John Paul's II message of Sollicitudo rei socialis and Evangelium vitae welcomes the donation of the organ as an act of true love for a neighbor and special honor for the donor. However, the message seems to be clouded by anxiety about making human organs "items of exchange or trade (...) because to use the body as an object is to violate the dignity of the human person" ${ }^{\prime 3}$ (John Paul $\mathrm{II}^{4}$ ). Discussing our findings and possible explanations in one of the ethics seminars (AMU, January 2018), students reported such anxiety despite the fact that organ trafficking is forbidden in EU countries. People who declare that they are not religious also respect bodily integrity. All observations considered, our hypothesis regarding the drop in the willingness of the elderly to donate is as follows: maturity is accompanied by the growth of awareness of their own bodily integrity as a value. On the other hand, in elderly people the willingness can also be inversely proportional to the state of their health. In Poland, statistically $65 \%$ of cancers affect the group $60+$. The immunological age (Hubbard \& Dashti 2011; Weiskopf et al. 2009; MacCormick 1978, 1172) ${ }^{5}$ seems not

1 According to the medieval theologists such as Origenes and Aquinas, "the soul is not the whole human being, only part of me; my soul is not me" (Aquinas 1993).

2 It is most likely that "such subjective and personal judgments, allowing similarities with in religion, ethnic group, and socioeconomic background to guide their choice" (see Rothman 1991, 111), potential organ donors contribute to "sectarian" (cf.) biomedical justice rather then to a fairness-like justice.

3 Those reasons seem more convincing than the general claim that "the social attitudes to organ transplantation are undoubtedly largely influenced by the position of the Catholic Church" (Antos \& Zelman 2006, 2). According to Gibek et al. (2017), no relevant inference of personal religious convictions and the willingness for organ donation was observed in Polish citizens. Gibek et al. examined several personal traits in Polish students and their relatives $(\mathrm{N}=102)$ which correlate with such a willingness. They discovered that persons with highest donation willingness level show maturity, sociability, vigorousness, curiosity, and independence. Divorced respondents would donate an organ post mortem more likely than other respondents (cf., 157).

4 On the other hand, contemporary culture is "capitalizing" body, health, wellness etc. (Williams 2003).

5 However, other sources indicate that people in their 50s and over make good donors and recipients, because biological age does not always go hand in hand with chronological age (see U.S. Department of Health and Human Services 2017). 
to have a significant effect on organ donation in Poland. Rather, psychosocial factors may have an impact on an elderly person's willingness to donate; among others, it is 39\% of population (CBOS 2017) which admits to anxiety about the vague procedures of decision making in the public health sector, in partular in the field of transplant surgery.

According to CBOS, "quite frequently the least educated do not approve of the procurement of donated organs", while in comparison "the lowest level of disapproval" is found among people with higher levels of education (CBOS 2012), and among representatives of administrative personel, and technical and economic professions, etc. The results of the CBOS study suggest that a person's level of education (regardless of the their study profile, e.g. the humanities, social sciences, life sciences, etc.) positively correlates with consenting to donate one's own organs, at least after death (ex mortuo).

In the subsequent section, we are chiefly concerned with the relationship between education and the willingness to be an organ donor, and this will be explained using the data made available to us by the team of Boratyński et al. (Questionnaire on the Bases of Transplantation Medicine 2016/7). On the one hand, intuition would lead one to expect the results to confirm a positive correlation between the respondents' education level and profile and, on the other hand, their willingness to donate their organs to other people "in need", and their awareness concerning the meaning and importance of transplantation.

\section{Research Aims and Methods}

The research was conducted by means of the Questionnaire on the Bases of Transplantation Medicine developed by W. Boratyński, P. Mularczyk, \& R. Danielewicz (see Boratyński et al. 2016/7). hand search method. Data were collected by W. Boratyński et al. The questionnaire consists of seven blocks of topics. In accordance with a comparative study conducted and reported below, the following topics have been abstracted from the entire tool:

- general acceptance of organ donation and transplant operations among students (Q. 1)

- a willingness to donate one's organs ex mortuo (Q. 2)

- a general acceptance of ex vivo organ donations (Q. 6)

- familiarity with the national law concerning transplants (implied consent) (Q. 9)

- transplantology- and clinical ethics courses that are included or not included in study programs (Q.12)

- familiarity with the decisive criteria of brain death in the context of procuring organs for transplants (Q. 13).

The questionnaire also includes a range of more specific or technical questions. In the following paper, we will describe the results of surveys completed by respondents $(\mathrm{N}=693)$, representing three different study profiles: 
- Public health ( $\mathrm{N}=482)$, data from two universities in Warsaw and Białystok,

- Philosophy ( $\mathrm{N}=142)$, data from two universities - in Warsaw and Poznań, and

- Psychology ( $\mathrm{N}=69$ ), data from one university in Cracow.

The respondents represented a cross-section of all the years of undergraduate bachelor's courses and post-graduate courses.

This analysis will focus on slightly different aspects than those focused on by Boratyński et al. (2016). We attempt to answer only the following questions:

1. Is there a correlation between study profiles and the frequency of a positive attitude towards transplantation, willingness to donate organs ex mortuo, or general approval of donation ex vivo?

2. Do the study profiles correlate in any way with an awareness of legal regulations, particularly with regard to organ donation and transplant policies?

3. Do university students declare any specific statements regarding to organ donation and transplant policies?

\section{The Results of the Questionnaire on the Bases of Transplantation Medicine}

Q. 1: General acceptance of procuring organs ex mortuo and transplantation (the percentage distribution for the three study profiles):

\begin{tabular}{|l|l|l|l|}
\hline $\begin{array}{l}\text { The number of people who } \\
\text { definitely or somewhat accept } \\
\text { transplantation. }\end{array}$ & $\begin{array}{l}\text { philosophy } \\
\text { (phil) }\end{array}$ & $\begin{array}{l}\text { public health } \\
\text { (pubHe) }\end{array}$ & $\begin{array}{l}\text { psychology } \\
\text { (psy) }\end{array}$ \\
\hline$\%$ & $90.85 \%$ & $96 \%$ & $99.31 \%$ \\
\hline
\end{tabular}

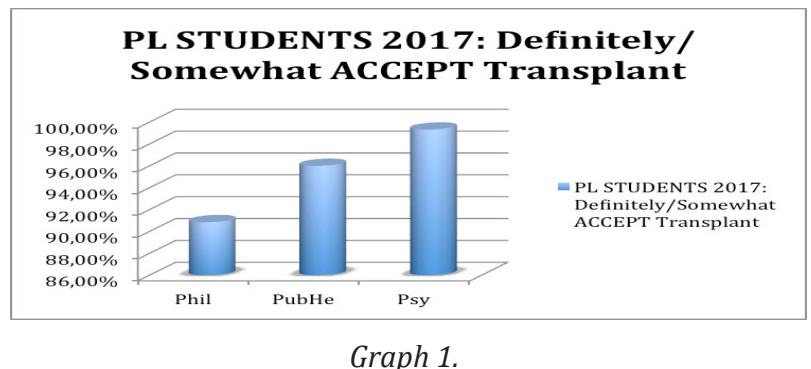

Q. 2: Willingness to donate one's own organs ex mortuo (percentages):

\begin{tabular}{|l|l|l|l|}
\hline $\begin{array}{l}\text { The number of people declaring } \\
\text { a willingness to donate their own } \\
\text { organs ex mortuo. }\end{array}$ & $\begin{array}{l}\text { philosophy } \\
\text { (phil) }\end{array}$ & $\begin{array}{l}\text { public health } \\
\text { (pubHe) }\end{array}$ & $\begin{array}{l}\text { psychology } \\
\text { (psy) }\end{array}$ \\
\hline$\%$ & $89.84 \%$ & $85 \%$ & $98.62 \%$ \\
\hline
\end{tabular}




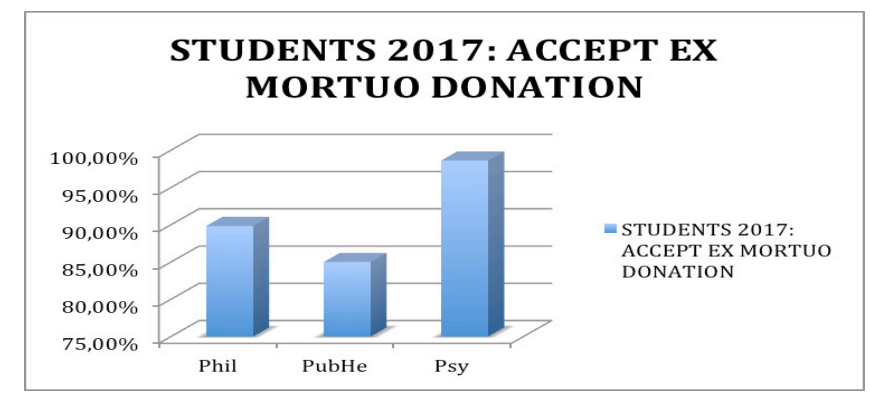

Graph 2.

Q. 6: Acceptance of ex vivo donation:

\begin{tabular}{|l|l|l|l|}
\hline $\begin{array}{l}\text { The number of people expressing } \\
\text { general acceptance of ex vivo } \\
\text { organ donation: }\end{array}$ & $\begin{array}{l}\text { philosophy } \\
\text { (phil) }\end{array}$ & $\begin{array}{l}\text { public health } \\
\text { (pubHe) }\end{array}$ & $\begin{array}{l}\text { psychology } \\
\text { (psy) }\end{array}$ \\
\hline$\%$ & $59.15 \%$ & $75.73 \%$ & $84.82 \%$ \\
\hline
\end{tabular}

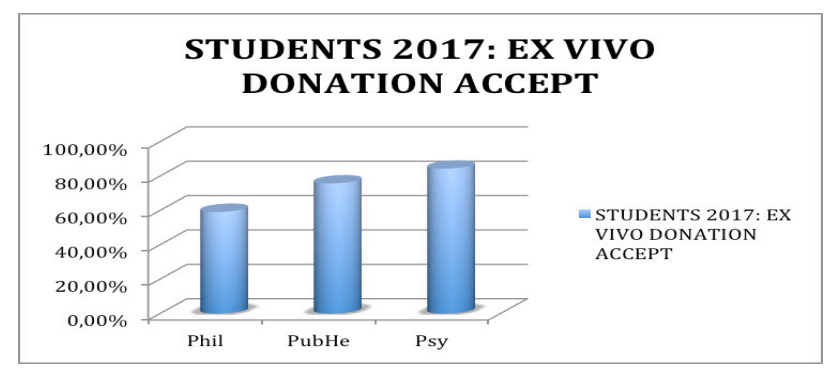

Graph 3.

Q. 9: Familiarity with domestic legal regulations governing the acquisition of organs for transplants:

\begin{tabular}{|l|l|l|l|}
\hline $\begin{array}{l}\text { Familiarity with domestic } \\
\text { legal regulations governing } \\
\text { the acquisition of organs for } \\
\text { transplants: }\end{array}$ & $\begin{array}{l}\text { philosophy } \\
\text { (phil) }\end{array}$ & $\begin{array}{l}\text { public health } \\
\text { (pubHe) }\end{array}$ & $\begin{array}{l}\text { psychology } \\
\text { (psy) }\end{array}$ \\
\hline$\%$ & $16.20 \%$ & $40.87 \%$ & $24.64 \%$ \\
\hline
\end{tabular}

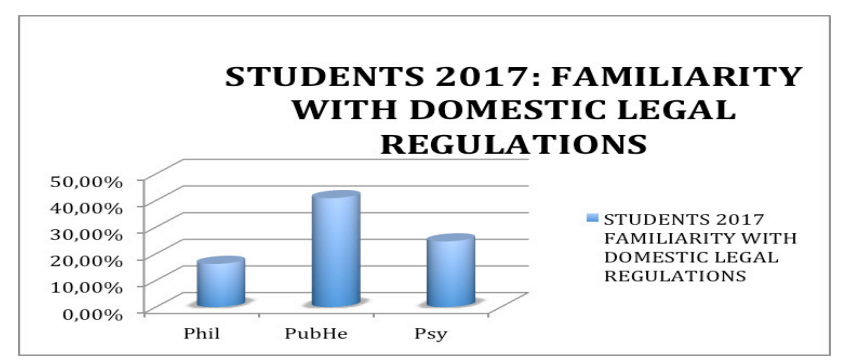

Graph 4. 
Q.12: Whether a course on transplantology/clinical ethics is included in the study profile.

\begin{tabular}{|l|l|l|l|}
\hline $\begin{array}{l}\text { A course in transplantation or } \\
\text { bioethics included in the major } \\
\text { study program }\end{array}$ & $\begin{array}{l}\text { philosophy } \\
\text { (phil) }\end{array}$ & $\begin{array}{l}\text { public health } \\
\text { (pubHe) }\end{array}$ & $\begin{array}{l}\text { psychology } \\
\text { (psy) }\end{array}$ \\
\hline$\%$ & $35.21 \%$ & $70.74 \%$ & $0 \%$ \\
\hline
\end{tabular}

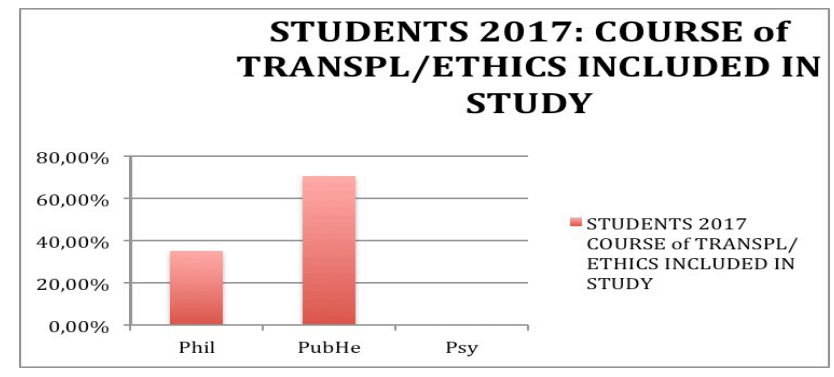

Graph 5.

Q. 13: Familiarity with the significance of the criteria of brain death in the context of acquiring organs for transplants:

\begin{tabular}{|l|l|l|l|}
\hline $\begin{array}{l}\text { Familiarity with the significance } \\
\text { of the criteria of brain death in } \\
\text { the context of acquiring organs } \\
\text { for transplants }\end{array}$ & $\begin{array}{l}\text { philosophy } \\
\text { (phil) }\end{array}$ & $\begin{array}{l}\text { public health } \\
\text { (pubHe) }\end{array}$ & $\begin{array}{l}\text { psychology } \\
\text { (psy) }\end{array}$ \\
\hline$\%$ & $55.63 \%$ & $67.01 \%$ & $88.41 \%$ \\
\hline
\end{tabular}

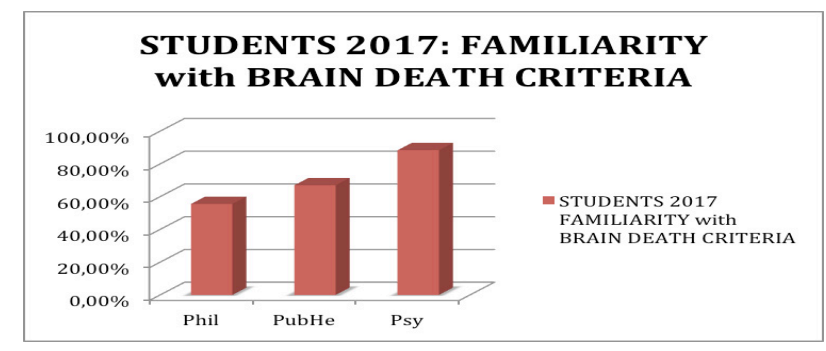

Graph 6.

\section{Examination and Interpretation of Results. Organ Donation Policies in Poland}

The results obtained do not necessarily confirm the hypothesis of a straightforward correlation between the level and profile of education and the awareness of the importance of transplants among students of the three study profiles, representing social sciences (psychology and public health, bordering on life sciences) and humanities (philosophy). The results provide a good opportunity to draw a few conclusions and posit more detailed - though not exhaustive - hypotheses. For the sake of clarity, we have grouped these into three points: 
1. In comparison with the answers provided by Poles to the questions of CBOS concerning their willingness to donate their own organs ex mortuo, which in 2012 stood at $74 \%$ (the answers 'definitely yes' and 'probably yes'), the willingness of students (trial $\mathrm{N}=693$ ) was $17 \%$ higher, standing at $91 \%$. This is a very significant difference that confirms the hypothesis that the level of a person's education correlates positively with their willingness to be an organ donor, in this case ex mortuo. However, 'education' does not necessarily mean formal/academic education for, according to the transplant survey, only 55\% philosophy students showed their trust in the brain death criterion ${ }^{6}$. According to professional sources, ex vivo donation happening in Poland has proved to be highly unexpected. Perhaps this will improve after the law is amended to meet EU requirements; clearly there is a need for conscious and concerted improvement in education on this topic (Sieradzka 2017).

2. In the context of the above mentioned correlation, at least two of the results gleaned from the research are surprising. While the respondents - representing three varied study profiles - did not differ from each other in terms of their attitude towards donating their own organs ex mortuo (Q. 2), a significant difference emerged in the answers to the question concerning the procurement of organs ex vivo (Q. 6). The general level of approval for ex vivo stands at $73.23 \%$ and is therefore significantly lower than the level of approval for the procurement of organs ex mortuo (91\%). Approval of ex vivo among students of psychology is relatively high, standing at $84.82 \%$, which is $25.67 \%$ higher than the approval of the same among philosophy students. This is all the more surprising as psychology students claim that they have not participated in any courses on the topic of transplantation, organ donation etc. Yet $35.21 \%$ of philosophy students state that they have participated in courses on transplantation (implicitly, in bioethics courses). On the other hand, public health students are twice as likely to attend such courses - as many as $70.74 \%$ of these students claim to have attended them. Our hypothesis is as follows: specialist academic knowledge does not necessarily lead to increased approval of ex vivo organ donation. For some reason, philosophy students show an attachment to the integrity of their own organisms and parts of the body more frequently than do the students of the other subjects in the survey. However, their general attitude to transplantation is similarly positive. Perhaps a deeper knowledge of psychophysiological conditions enables corporeality to be perceived in a more 'inter-corporeal' manner, e.g., as potentially useful for recipients of allografts (Shildrick 2015). In contrast, focusing on the spiritual values of the human condition maintains the mystery of the metaphysical potentialities of the human body; this includes a body that finds itself in the dramatic, existential need of a transplant. This suggests bioethics, anthropology, phenomenology, and philosophy of a

6 The Polish Transplantation Act of 1 July 2005 adopted the brain death definition "as a citerion for a person's death" (Antos \& Zelman 2016, 3; compare Wijdicks 2002). 
living-and-lived body to be mandatory components of study programs. Academia prefers to deal with futurist problems (as for example the trans-human condition), yet there are also "imperatives of now" (speaking with Fanon). Human beings are still subjected to vital and pressing needs, particularly when life is endangered due to a permanent injury or the loss of an organ for which an artificial prosthesis is unavailable.

3. Another unexpected result was the lack of familiarity with the national legislation on both complex topics, e.g., brain death diagnostics and procuring organs for ex mortuo transplants. Admittedly, none of the questions explicitly contained the phrase 'implied consent', which is a key element of this legislation, however in Q. 9 one option clearly states that 'no objection expressed during one's lifetime is enough' to constitute consent from the deceased (potential) donor. In line with expectations, public health students most often chose the correct answer ( $40.87 \%$ of the group); whereas philosophy students gave the least number of correct answers (16.20\%), despite the fact they attend more specialised courses connected with the fields of bioethics during their studies.

Our hypothesis for explaining the uncertainty associated with the phrase 'no objection/opposition' is as follows: for the respondents, consent justified through 'no opposition' involves the logic of double negation. The essence of double negation is that it brings back the original meaning of that which was negated. In terms of implied consent, 'no opposition' may signify a new state of affairs: consent in the affirmative sense.

Furthermore, according to Polish legislation, 'consent' should be assumed (opting out, as in Zoń (2015) after the death of a potential organ donor: the issue here does not concern 'explicit' consent (opting in) the obviousness of which depends on material evidence (an actual document expressing consent). In this sense, 'against transplantation' is more obvious than 'implied consent', or in other words: "objection to the removal of organs, tissue and cells for post mortem transplantation," which a Polish citizen can declare throughout their lifetime in the Central Register of Objections (CRS). When it comes to presumption, it is easy to confuse this with a speculation or 'tacit agreement', which constitutes a separate legal category. The counter-intuitive sense of such statements is a greater challenge for the human mind than the sense of affirmative statements or single negations. As Pinker writes, there is an increased cognitive load if something is not the same or different (Pinker 2014), and this is an area for psycholinguistic research (Johnson Laird \& Tridgell 1972, 8791). Wojcieszak (2015) suggests that it is relatively easy to undermine presumptions: "the way to question such presumptions are various forms of objection expressed by the donor while alive" (Wojcieszak 2015, 195). The lack of an expressed objection will not prevent the situation arising wherein an outside party, opposing the removal of organs from a deceased family member, will 'presume' the member's objection, justifying their presumption legally sanctioned - with 'presumed consent'. In the face of the lack of objection while alive, a medical institution is entitled to dispose of a deceased body. However, it is oftentime a doctor who tries to get consent for donation from a deceased family. As a consequence, 
the family protracts their decision and, finally, it is too late for transplantation (Wojcieszak $2015,178)$.

According to Szewczyk (2009), harvesting an allograft implies harming a donor, thus it also trespasses the doctor's duty to primum non nocere. The previously required donor's consent should protect the doctor against such consequences. However, following the consent principle is a necessary, but insufficient condition for the moral justification of organ donotion. „Approving an action does not automatically make it morally or legally sanctioned. Instead it would be the aim of the action (...), here - a patient's good" (Szewczyk $2009,162)$, which does not concern the case of organ donors This example of a legal rule designed to be quasi-morally justified (for it involves a donor's autonomy) shows how complex bioethical justifications can be, despite the fact that laws and procedure provide an efficient shield against real harm, loss, risk and further kinds of wrongdoing. Moreover, the followers of the classical principle of double effect argue that harming a donor does not provide an appropriate means for securing a recipient's good: „it is solely the ,second effect' of a doctor's action and a donor's decision" (cf. 162). As was previously mentioned, students of the faculty of philosophy were asked twice (2018 and 2019) to explain such semantics as ,consent' and ,objection. Both groups showed their confusion, which is quite common when trying to intuitively define big, categorial terms such as truth and autonomy. As we gave the controversial example of a Chinese teenager who in 2011 sold one of his kidneys to get money for buying a laptop, smartphone, etc. (but is seriously disabled today), students instantly figured out that autonomous consent encompasses more than approval, that is, it requires decision making and if it is a moral decision, there are various reasons and values which are different to autonomy. They finally discovered that autonomy is not a value, but, rather, a person's competence to make judgments and decisions based on the normative criteria (Nestorowicz 2010, 32-33).

Despite certain difficulties involved in the phrase 'no opposition', there would seem to be no logical reason why psychology students and public health students participating in our survey should fare better with such a task than philosophy students, who deal with logical and ontological issues on a day-to-day basis. In the light of these somewhat paradoxical results, we draw attention to the fact that the normative subjects studied were not the sole source of the respondents' knowledge about transplantology and transplant policies. They have also absorbed information from the Internet (over $60 \%$ of philosophy indicated this as a source), the press, professional literature ${ }^{7}$ and social campaigns for organ donations. The second component of our hypothesis concerning the ambiguity of regulatory terms in social

7 Professional literature (and SciFi) also contributes to the macabre imaginary of transplantation as "neo-cannibalism" and "scavenging on s cadaver" (Wolniewicz 1993; 2013). Up until quite recently - and this was not only in Poland - "to receive a foreign organ into your own body was perceived as repulsive. It was compared violating the taboo on cannibalism, and even referred to as neo-cannibalism or medical cannibalism. It has also been suggested that organ transplants differ from cannibalism only in the way in which one person's body becomes part of another's" (Nowacka 2003, 231). According to Nowacka, "transplantology is a field of medicine that saves lives solely through death or injury to other bodies" (cf., 232). 
interpretation is as follows: media reports and discussions are full of ambivalent content that present 'implied consent' in an ambiguous light ${ }^{8}$. Critical debates which precede and comment on legislation coming into force can arouse distrust and - due to the permanent nature of virtual data - can shape awareness of the law as much as the proper functioning of the law and the resulting benefits. In addition to sound critical reflection, it is expected that public media in Poland should update their knowledge pools and promote trust in medical technologies, public health institutions and their legal foundations 9 .

Concerning the law on the procurement of organs, it is expected that the publishing media in Poland should facilitate the understanding of the declaration of intent and implied consent despite the fact that the Poltransplant Center, which has operated since since 1996, and the National Program for the Development of Medical Transplantation ${ }^{10}$ conduct their own web sites. The number of donors has declined in recent years, especially in comparison with the hundredfold increase in the number of bone marrow donors in 1993-2003 (Muszala 2016, 128-131). An increase or decrease in the willingness of citizens to donate ex mortuo or ex vivo depends on many factors, which are sometimes variable. One of the invariable factors is certainly the compilation of thorough information which is easily available. Legal regulations provide only a procedural framework, but not always security ${ }^{11}$, as the research findings and discussions reported above have already shown. In this sense, organ donation pertains to the domain of ethics and individual, rational and independent decision making. The issue of decision makers' ethical security overlaps the domain of clinical and procedural ethics, but in the case of organ donation, the individual, professional (medical) and social domains remain distinct, but, at the same time, overlapping areas ${ }^{12}$. Article 36 of the Polish Code of Medical Ethics states that only "the procurement of cells, tissues or organs from a living donor for transplantation purposes may be made only from an adult with his/her written consent, in full voluntary conditions, after he/she has been informed of any possible consequences associated with this procedure. It is unacceptable

8 For ex. illegal allograft harvesting and trafficking, organs' wilful appropriation, brain- and brain stem death controversies, etc. (Biesaga 2006, 20-24; Morciniec 2009, 78-92).

9 The media facilitate health communication in societies: "regardless of the context in which communication occurs, the basic process remains the same: information about scientific health fndings must be converted from technical language into communications that lay audiences can more easily understand" (Nelson et al. 2009, 73); for the advantages and disadvantages of telemedicine see Tyrrell (2002).

10 See http://www.poltransplant.org.pl/uchwala_rm_1642010.html. In the European Union organ commercialism is prohibited, but it is discussed elsewhere (Hippen et al. 2009, 1053-1061; Thomas 2013, 111-129).

11 Procedural security refers, of course, to ethical security; both types of security were the subject of lively debate even before the regulation of implied consent, opposition, etc. was introduced (Biesaga 2006).

12 For the sake justice, both organ donation and allografts' distribution should be regulated "as much possible through public policy rather than free enterprise (...) It is most important to stress this (...) that unconditionality of donation should not be treated as a constraint on the discussion of policy. Even if there is no objection of principle to directed donation, there would inevitably be strong constraints of practicality. (...) bequeating organs cannot be like bequeating most other possessions, because they have to be collected, preserved, [redistributed] and transferred" (Radcliffe Richards 2012, 198-199). 
to procure a vital organ from a live organ donor." In the second case (ex mortuo), Article 33 of the Code states that "a physician may procure cells, tissues and organs from the body for transplantation, unless the deceased has expressed an objection to this while alive"13. The articles mentioned above do not address decisions of potential donors. Donors' decisions rather belong to the domain of personal morals.

After having analyzed Q. 13 (familiarity with brain death criteria and diagnostics) a significant disparity in familiarity reported by students became apparent. Philosophy students are ca. 33\% less familiar with brain death criteria than psychology students (and ca. $12 \%$ less familiar than public health students). Those results are not surprising for researchers. Brain death criteria are a highly complex and it is a developing clinical topic. They are a compulsory part of medical studies curricula. However, public health domain does not exactly belong to medical studies; rather, it combines interdisciplinary knowledge, which includes sociological, institutional, procedural, bioethical and organizational elements. Regarding posthumous donation, both potential donors and recipients would benefit from professional counseling in the field of brain death criteria. This kind of counseling would be expected from public health professionals in a society as unstable in its willingness to donate as Polish society is:

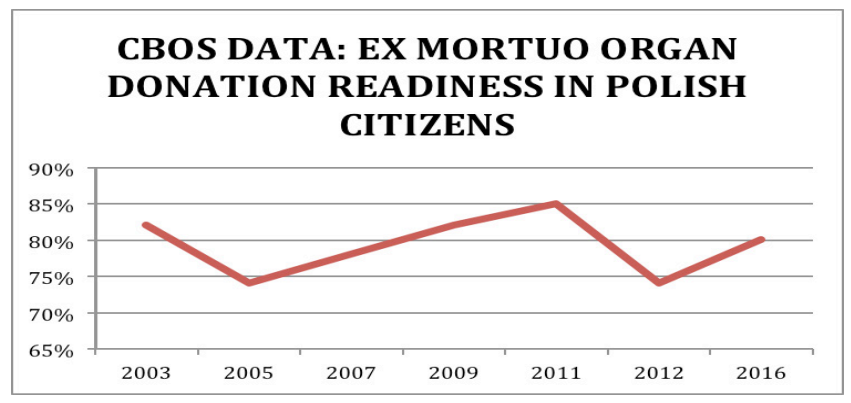

Graph 7. Data compilation based on information published by CBOS (2012-2016).

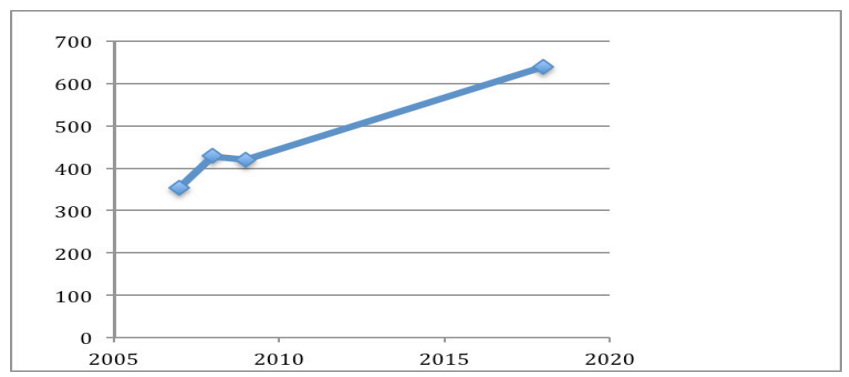

Graph 8. Ex vivo donations (source: Poltransplant 2007-2018 ${ }^{14}$ ).

\footnotetext{
13 Muszala explains that there are "two models of post-mortem consent: the model of explicit consent (e.g. in the United Kingdom) and the model of implied consent", applied by the Polish legislator. The latter assumes that "any deceased person is a potential organ donor if he/she has not objected previously." The objection may be expressed in three ways: 1) in the form of a declaration in the Central Register of Objections, objecting to the collection of cells, tissues and organs from human corpses; 2) written declarations signed by hand; 3 ) oral declarations made in the presence of at least 2 witnesses, confirmed in writing by them" (Muszala 2016), the legal basis: The Act of 1 July 2005 on the Procurement, Storing and Transplantation of Cells, Tissues and Organs, Journal of Laws, item 793 (see Haberko \& Uhrynowska-Tyszkiewicz 2014). A separate, overlooked issue is the donation of an organ by a minor and the procurement of organs from the body of the child (Haberko 2010, 97-106).
} 
This is probably different in the case of philosophy and psychology students. They focus on ethical issues as well as on right actions and just procedures. When starting to make initial semester students (faculty of philosophy, UAM 2018) familiar with brain death criteria and transplant policies, one of the authors (E. Nowak) discussed, among others, four documents: the Ad Hoc Committee of Harvard Medical School declaration (1969), Polish biomedical law (2005), the Polish Code of Medical Ethics (KEL), and the objections against brain death criteria expressed by Hans Jonas in 1969 (Jonas 2010, $536)^{15}$. We discussed these documents, including the Polish declaration of disagreement to become a posthumous organ donor. Students could seriously work on authentic official sources. They were able to follow the basic stages of how to make and how to declare an autonomous, deliberated and professionally assisted decision as a potential organ donor; they also learned how to declare their own disagreement. They were impressed with the precision of the (double) brain death diagnostics procedure recommended by the Polish Code of Medical Ethics (KEL 38, 2016). Simultanously, they were surprised by the multifacetedness of death and its processual nature, which evokes philosophical reflection. As anticipated, they also addressed numerous legal issues and expressed their opinions about them. In particular, they critically assessed the "opting out" formula as confusing when compared to the more suitable solutions and institutions in the UK and U.S. (with which they seem to be more familiar than with the Polish). They suggested that the donor's presumed declaration should be assisted by a notary's office in order to protect it from manipulation by third parties. They explicitly questioned the lack of objection to by equated with "consent". It is worth mentioning that the course was based on the findings presented in this paper. Students could learn from former students' experiences and also discuss their own expectations on teaching bioethical topics in the next academic year when they become more specialized in their curricula.

\section{Conclusions. A Plea for Improving Health Communication Skills in University Students}

The research findings discussed here reveal the most recent social views of organ

15 Students were previously confronted with basic scientific facts in the field and they communicated their "thoughts about the phenomena, and the values (...) [they] attach to the phenomena itself", their preoriginal intuitions and concerns (alternately, multicultural groups, Siverly \& Corsiglia 2001 talk about indigenous knowledge; see also Cohen 2002), and "the various ways we have of understanding and accounting for the phenomena" (Cobern \& Loving 2001; 2008) to display - and respect - the multiplicity of moral beliefs and epistemological pluralism due to the controversial criteria of brain death diagnostics. The teacher tried to maintain a trustful, inclusive discursive atmosphere and not to impose ultimate truths (which is typical for scientism). According to Zeyer (inspired, among others, by Rawls) "a science teacher should accept the proviso, i.e., he or she should not support scientistic practice in the classroom-neither on the epistemological level (as forwarded by Cobern and Loving) nor on any other level of theoretical and practical reasoning. The avoidance of scientism does not ,only' become an epistemological issue, but also one of applied ethics in science education" (Zeyer 2008, 1099). 
donation and transplant policies in Poland ${ }^{16}$. Butfirstand foremost, they show us academics that more efficient educational tools must be developed to promote factual and ethical knowledge about organ donation and transplant policies for students. Decisions on organ donation are made autonomously, but making deliberate and principled decisions (and consent) on such demanding topics as organ donation can be advanced by transparent and available knowledge (Morgan \& Miller 2002) ${ }^{17}$. "Biological life constitutes (...) the foundation of personal life - conscious and autonomous. Transplant surgery is one of the new guardians of this foundation" (Nowacka 2003, 232). While biological allograft tissues and organs are material and passive objects, it is moral agents (donors and their relatives, recipients, professional decision makers, e.g., surgeons, clinical psychologists, immunologists, anesthetists, etc.) whose voices are decisive for the increase of successful transplantations.

Our recent experiences in academic ethical education show that students become competent, e.g., considered and careful judgment makers when they are trained and not only instructed by experts. Unlike elsewhere, in Poland biomedical, health related decisions are almost exclusively assisted by legal institutions and clinical psychologists (Brzeziński, Toeplitz, \& Winiewska 2004). Ethical expertise rather belongs to a doctor's competence, whereas a patient's autonomy encompasses little more than consent or objection. The patient's broader judgment and activism was demanded by Paweł Łuków (2005), however, an organ donor's position is different than a patient's. A donor's judgment would rather spring from Rawls' early concept of a considered judgment (Rawls 1951) whose descriptive aspects initially prevail and will be completed by a normative account through trainings (here meant as a part of standard ethics course). Dedicated clinical bioethicists would explore a judgment's full justification and explanation ${ }^{18}$. As organ donation (and reception) is a kind of social cooperation (Tomasello 2009) which pretends to contractual fairness (but which is, at the same time, asymetric), organ donors contribute to both interpersonal practice and subjective protojustice, which is also interpersonally mediated; however, in the case of organ donation its subjective moment remains irreducible. Basing decisions upon less intuitive, more explicit and objective moral rules (Rawls 1951, 77) would require a higher, reflexive and principled judgment. Therefore, making decisions for organ donation in a responsive and responsible way might be challenging for persons, insofar as they should do so as compassionately (Zabdyr-Jamróz

16 For information available online see Polski Portal Transplantacyjny, http://www.przeszczep. $\mathrm{pl} /$; internet users also have access to the Medonet portal. As the latter explains, Polish transplant law does not apply to genital allografts, generative cells, sexual glands, germinal and embryonal tissues.

17 Ethics in its practical variant, and in particular "bioethics in action," as Szewczyk stresses, reacts both to the dynamics of its doctrine and to the dynamics of vital social needs, including the needs of patients (Szewczyk 2009, 153; Kaufman 1978, 1173-1175).

18 According to Glassen, moral judgments have no objective validity, but they intend to say something about which can be proved and disproved, explained and justified; and "what we intend to assert by our moral judgments (...) that's what you philosophers are here for, to find" (Glassen 1959, 61). 
2015), consideratedly and solidarily as do lay people (Williams and Popay 2001), but not necessarily experts- (Rothman 1991 ${ }^{19}$ ), theorists- and other professionals. Academic teachers have favorable opportunities to promote health communication skills in students. Teaching methods such as combining intuition with thinking and sensing (Allen \& Brock 2000, 34-35; Gwyn 2002; Parrot 2009), confronting reflection with data ("data driven learning and experiential education," Brown et al. 2006, 123), suport of informed consent (Nowak 2014), educating, and empowering (Parvanta et al. 2011, 11), taboo-less and openly discussing public health related challenges and dilemmas (Durczyński et al. 2011; Scrambler \& Martin 2001), training identification with organ recipients, role- and perspective taking (Manyalich et al. 2013), etc. can improve their future willingness to donate an organ and their reasoned activism in this area (Wu \& Tang 2009). But first and foremost, teaching medical ethics requires favorable learning environment e.g. some opportunity of guided reflection, free speech, confronting opposite arguments, roletaking etc. (Schillinger 2006). Furthermore, teaching medical ethics

is not just a matter of learning different ethical theories, like learning more facts or a new language. (...) it is certainly not about accepting different opinions as being equally valid as one's own. It is about having and holding a worldview and trying to persuade others to see the world in our way, whilst acknowledging the similarly strongly held views of our opponents. This acknowledgment is a matter both of courtesy and of practical wisdom; we refine our views by exposure to the world (Hughes 1995, 20-30).

\section{References}

Allen J. \& Brock S. A. 2000. Health Care Communication Using Personality Type. Patients Are Different. London - Philadelphia: Routledge.

Antos E. \& Zelman M. 2016. "Issues Affecting the Perception of Organ Transplantation in Polish Society." Journal of Public Health, Nursing and Medical Rescue 3(16):1-9. Aquinas. 1993. Selected Philosophical Writings. Selected and trans. by T. McDermott. New York:Oxford University Press.

Biesaga T. 2006. "Wobec zgody domniemanej i zawłaszczania zwłok do transplantacji”.

Medycyna Praktyczna 1(26):20-4.

19 Rothman's portrayal of medical professions is ambiguous, whereas "quite ordinary people" as members of lay committees made "life-or-death decisions" and selected "fortunate patients", doing so "case-by-case", arbitrarily, but in an increasingly just manner, to protect the allocation of scarce medical resources from the abuse of professionals' authority (Rothman 1991, 150-151). In making choices "the committee transmitted a message (...) 'the acceptance of the principle that all segments of society, not just the medical fraternity should share the burden of choice as to which patients to treat and which to let die. Otherwise Society would be forcing the doctors to play God" (cf., 151). From a historical perspective, "professional criteria were of (...) limited [ethical] relevance" (cf., 110) before the bioethical turn after World War II towards case-based ethics (Fallorientierte Ethik) see Hick (2007). 
Boratyński W., Mularczyk P., \& Sarnacka E. 2016. “Opinions and Attitudes of Students of

Public Health to the Issues of Transplantation Medicine". Prog Health Sci 6(2):141-7.

Brown B., Crawford D., \& Carter R. 2006. Evidence-Based Health Communication. New York: Open University Press.

Butler R. \& Parr H. 1999. Mind and Body Spaces - London: Routledge.

Brzeziński J. \& Toeplitz-Winiewska M. 2004. Praktyka psychologiczna w świetle standardów etycznych. Tarnów: Wydawnictwo Academica SWPS.

Cahill K. C. \& Ettarh R. R. 2011. „Attitudes to Cadaveric Organ Donation in Irish Preclinical Medical Students." Anatomical Sciences Education 4:195-9.

CBOS. 2016. Postawy Polaków wobec transplantacji narządów. Komunikat z badań nr 119/2016. Warszawa: Fundacja CBOS.

CBOS. 2012. Postawy wobec przeszczepiania narządów. Komunikat z badań, BS/105/2012, Warszawa: Fundacja CBOS.

Cobern W. W. \& Loving C. C. 2001. "Defining 'Science' in a Multicultural World: Implications for Science Education." Science Education 85:50-67.

Cohen L. 2002. "The Other Kidney: Biopolitics beyond Recognition," in N. ScheperHughes \& L. Wacquant (Eds.), Commodifying Bodies. London: Sage Publications (9-29).

Cobern W. W. \& Loving C. C. 2008. "An Essay for Educators: Epistemological Realism Really Is Common Sense." Science \& Education 17:425-47.

Czerwiński J., Antoszkiewicz K., Pszenny A., Wałaszewski J. 2009. “Present Data on Organ Donation and Transplantation in Poland." Transplantation Proceedings 41(8):2955-8.

Durczyński A., Dąbrowska A., \& Strzelczyk J. 2011. “Organ Transplantation Remains Taboo Topic in Polish Families - Small Town Youths Survey Results." Clin Exp Med Lett 52(1-2):53-5.

Edwards M. J. et al. 2011. "Limb Amputations in Fixed Dystonia: A Form of Body Integrity Identity Disorder." Movement Disorders 26(8):1410-4.

Gibek K., Lickiewicz J., \& Serednicki W. 2017. “Osobowość i postawa religijna a gotowość do donacji narządów". Anestezjologia i Ratownictwo 11:152-8.

Glassen P. 1959. “The Cognitivity of Moral Judgments.” Mind 68(269):57-72.

Gwyn R. 2002. Communicating Health and Illness. London - Thousand Oaks - New Delhi: Sage Publications.

Haberko J. \& Uhrynowska-Tyszkiewicz I. 2014. Ustawa o pobieraniu, przechowywaniu $i$ przeszczepianiu komórek, tkanek i narządów. Komentarz, Warszawa.

Haberko J. 2010. “Prawne aspekty sekcji zwłok małoletniego”. Państwo i Prawo 10:97106.

Habermas J. 1983. Moralbewußtsein und kommunikatives Handeln. Frankfurt am Main: Suhrkamp.

Hick Ch. (Hg.) 2007. Klinische Ethik. Heidelberg: Springer. 
Hippen B., Friedman Ross L., \& Sade R. M. 2009. “Saving Lives Is More Important Than Abstract Moral Concerns: Financial Incentives Should Be Used to Increase Organ Donation." Ann Thorac Surgery 88(4):1053-61.

Hubbard W. J. \& Dashti N. 2011. "Aging and Transplantation - A Topic for Biomedicine or Bioethics?" Aging and Disease 2(2):181-5.

Hughes J. 1995. "Ultimate Justification: Wittgenstein and Medical Ethics." Journal of Medical Ethics 21:25-30.

Johnson Laird P. N. \& Tridgell J. M. 1972. "When Negation Is Easier Than Affirmation.” Quarterly Journal of Experimental Psychology 24:87-91.

Jonas H. 2010. "Gehirntod und menschliche Organenbank: zur pragmatischen Umdefinierung des Todes," in H. Jonas, Organismus und Freiheit. KGA, Bd. I/1, ed. by H. Gronke. Freiburg in Breisgau - Berlin - Wien: Rombach (511-36).

Kaufman M. 1978. “Orthodoxy in Medicine," in W. T. Reich (Ed.), Encyclopedia of Bioethics. New York - London: The Free Press \& Collier Macmillan Publishers.

Lind G. 2015. "How to Teach Morality. Promoting Deliberation and Discussion, Reducing Violence and Deceit." Berlin: Logos.

Łuków P. 2005. Granice zgody: autonomia zasad i dobro pacjenta. Warszawa: Wydawnictwo Naukowe Scholar.

Manyalich M., Guasch X., Páez G., Valero R., \& Istrate M. 2009. “ETPOD (European Training Program on Organ Donation): A Successful Training Program to Improve Organ Donation." Transplant Int 26(4):373-84.

McCormick R. A. 1978. “Ethical Principles/Organ Transplantations.” In T. Reich (Ed.), Encyclopedia of Bioethics. New York - London: The Free Press \& Collier Macmillan Publishers.

Morciniec P. 2009. “Ludzkie zwłoki jako obiekt badawczy: dowolność działań czy normowanie?" Diametros 19:78-92.

Morgan S. E. \& Miller J. K. 2002. "Beyond the Organ Donor Card: The Effect of Knowledge, Attitudes, and Values on Willingness to Communicate About Organ Donation to Family Members." Health Communication 14(1):121-34.

Muszala A. 2016. “Kodeks Etyki Lekarskiej: Zgoda na pobranie narządów i tkanek do przeszczepienia“. Medycyna Praktyczna 10:128-31.

Nelson D. E., Hesse B. W., \& Croyle R. T. 2009. Making Data Talk. Communicating Public Health Data to the Public, Policy Makers and the Press. Oxford, NY: Oxford University Press.

Nestorowicz M. 2010. Prawo medyczne. Toruń: Wydawnictwo Dom Organizatora.

Nestorowicz N. \& Śliwka K. 2009. „Pobieranie ze zwłok komórek, tkanek i narządów do celów naukowych - problem prawny i medyczny“. Prawo i Medycyna 4.

Nowacka M. 2003. Etyka a transplantacje. Warszawa: PWN. 
Nowak E. 2017. “Ustrój cielesny w doświadczeniu podmiotowym i międzypodmiotowym. Zrozumieć fenomen allotransplantacji”. Filozofia i Nauka 5:61-87.

Nowak E., Pfitzner R., Koźlik P., Kozynacka A., Durajski Ł., \& Przybyłowski P. 2014.

"Organ Donor Cards-Concepts Versus Reality: A Study Among Academic Students in Poland." Transplantation Proceedings 46(8):2519-29.

Parrot R. 2009. Talking about Health: Why Communication Matters? Malden, MA: WileyBlackwell.

Parvanta C., Nelson D. E., Parvanta S. A., \& Harner R. N. 2011. Essentials of Public Health Communication. Sadbury, MA: Jones \& Bartlett Learning LLC.

Paszkowska M. 2008. "Podstawy prawne przeszczepiania komórek, tkanek i narządów". Zeszyty Naukowe Ochrony Zdrowia. Zdrowie Publiczne i Zarzq̨dzanie 4(1):18-33.

Pinker S. 2014. The Sense of Style: The Thinking Person's Guide to Writing in the $21^{\text {st }}$ Century. New York: Penguin.

Polityka Zdrowotna 2018. Retrieved from http://politykazdrowotna.com

Radcliffe Richards J. 2012. The Ethics of Transplants. Why Careless Thought Costs Lives. New York: Oxford University Press.

Rawls J. 1951. „Outline of a Decision Procedure for Ethics.“ Philosophical Review 60(2):177-97.

Rawls J. 1975. „The Independence of Moral Theory." Proceedings and Addresses of American Philosophical Association 5

Rawls J. 1993. Political Liberalism. New York: Columbia University Press.

Rowiński W. \& Wałaszerski J. 2005. Transplantologia kliniczna. Warszawa: PZWL.

Rothman D. J. 1991. Strangers at the Bedside. History of How Law and Bioethics Transformed Medical Decision Making. USA: BasicBooks / A Division of HarperCollins Publishers.

Schillinger M. 2006. Learning Environment and Moral Development: How University Education Fosters Moral Judgment Competence in Brazil and Two German-Speaking Countries. Dissertation, Konstanz.

Scrambler G. \& Martin L. 2001. "Civil Society, the Public Sphere and Deliberative Democracy", in G. Scrambler (Ed.), Habermas, Critical Theory and Health. New York: Routledge (182-205).

Shildrick M. 2015. "Staying Alive: Affect, Identity, and Anxiety in Organ Transplantation." Body \& Society. Special Issue: Estranged Bodies 21(3):3-19.

Sieradzka A. 2017. Tajemnice transplantacji. Warszawa: PWN.

Snively G. \& Corsiglia J. 2001. „Rediscovering Indigenous Science: Implications for Science Education." Science Education 85:6-34.

Szewczyk K. 2009. Bioetyka. Medycyna na granicach życia. Warszawa: PWN.

Szewczyk K. 2007. Bioetyka. Pacjent w systemie opieki zdrowotnej. Warszawa: WN PWN. 
Theodorakopoulou E., Meghji S., Pafitanis G., \& and Mason K. A. 2017. "A Review of the World's Published Face Transplant Cases: Ethical Perspectives." Scars, Burns \& Healing 3:1-10.

Thomas R. 2013. "A Market Price for Organs?" New Bioethics 19(2):111-29.

Tomasello M. 2009. Why We Cooperate. Cambridge, Mass. - London, England: MIT Press. Tyrrell S. 2002. Using Information and Communication Technology in Healthcare. Oxon: Radcliffe Medical Press.

U.S. Department of Health and Human Services. 2017. "Is There an Age Limit for Organ Donation?" Health Resources \& Services Administration U.S. Department of Health and Human Services, https://www.organdonor.gov/about/donors/seniors.html (retrieved on 28 Dec 2017).

Weiskopf D., Weinberger B., \& Grubeck-Loebenstein B. 2009. "The Aging of the Immune System." European Society for Organ Transplantation 22:1041-50.

Wijdicks E. F. M. 2002. "Brain Death Worldwide. Accepted Fact But No Global Consensus in Diagnostic Criteria." Neurology 58:20-5.

Williams G. \& Popay J. 2001. "Lay Health Knowledge and the Concept of the Lifeworld," in G. Scambler (Ed.), Habermas, Critical Theory and Health. New York: Routledge (25-44).

Williams S. J. 2003. "What Is Health? Thinking through the Boundaries of the Body", in Medicine and the Body. London: Sage Publications Ltd. (29-43).

Wojcieszak A. 2015. "Forma sprzeciwu na pobranie komórek, tkanek i narządów ze zwłok ludzkich". MW 7.

Wolniewicz B. 1993. Filozofia i wartości. Warszawa: WFiSUW Editions.

Wolniewicz B. 2013. "Przeszczepy to ludożerstwo" [Transplants are acts of cannibalism]. Superexpress, http://natemat.pl/77539,prof-wolniewicz-uwaza-ze-przeszczepyto-forma-ludozerstwa-nie-oddalby-nerki-nawet-wlasnej-corce-powiedzialbymniech-umrze (retrieved on 31 Nov 2017).

Wu A. M. S. \& Tang C. S. 2009. "Solving the Dilemma: Family Communication About Organ Donation Among Chinese, Japanese and Caucasian American College Students." Journal of Applied Social Psychology 39(7):1639-59.

Zabdyr-Jamróz M. 2015. “The Veil of Ignorance and Solidarity in Healthcare: Finding Compassion in the Original Position." Diametros Special Topic Solidarity and Justice in Health Care 43(March):79-95.

Zeyer A. 2008. " Public Reason and Teaching Science in a Multicultural World: a Comment on Cobern and Loving: An Essay for Educators... in the Light of John Rawls' Political Philosophy." Science \& Education 18:1095-100.

Zoń K. 2015. Sprzeciw na pobranie komórek, tkanek lub narzq̨dów post mortem w przypadku osób małoletnich (An unpublished master thesis). Digital Library of Wrocław University. 


\title{
Wojciech Boratyński (Warsaw), Grażyna Bączek (Warsaw), Agnieszka Dyzmann-Sroka (Poznań), Agnieszka Jędrzejczak (Poznań), Aleksandra Kielan (Warsaw), Paulina Mularczyk-Tomczewska (Warsaw), Ewa Nowak (Poznań), Małgorzata Steć (Cracow), Mariusz Szynkiewicz (Poznań) \\ Examining Lay People's vs. University Students' Perspectives on Organ Donation and Improving Health Communication in Poland
}

\begin{abstract}
Given that organ transplant is a standard medical technology admitted in medical practice, and taking into consideration that Polish transplantology is regarded among the most advanced in the world one should expect to find similarly high levels of acceptance in interviewees asked for their opinion on vital organ transplantation and their willingness to donate a paired organ ex vivo, or a vital organ ex mortuo in order to rescue the life of a recipient with a missing vital organ. The paper presents research build on the societal assessment of vital organ donation and transplant policies in Poland with the focus on students. Data have been collected at three different universities (Boratyński et al., Questionnaire on the Bases of Transplantation Medicine 2016/7). Various assessments concerning a vital organ donation have been observed. The authors discuss educational factors contributing to these variety including factual knowledge and ethical issues.
\end{abstract}

Keywords: organ donation; societal assessment; transplant policies in Poland; promoting decision making; health communication and discourse in university education

Ethics in Progress (ISSN 2084-9257). Vol. 9 (2018). No. 2, Art. \#8, pp. 99-117.

Creative Commons BY-SA 3.0

Doi:10.14746/eip.2018.2.8 